Type of the Paper (Article)

\title{
Tracking Sustainable Development Goals - A Case Study of Pakistan
}

\author{
Anam Javeed 1, Muhammad Yar Khan 2, Mobashar Rehman ${ }^{3 *}$, Asif Khurshid ${ }^{4}$ and Manzoor \\ Ahmed Hashmani ${ }^{5}$ \\ ${ }^{1}$ University of Wah, Wah Cantt, Pakistan; dr.anam.javeed@hotmail.com \\ ${ }^{2}$ COMSATS University Islamabad, Wah Campus, Pakistan; muhammadyar@ciitwah.edu.pk \\ ${ }^{3}$ University Tunku Abdul Rahman, Kampar, Malaysia; mobashar@utar.edu.my \\ ${ }^{4}$ Bahria University, Islamabad, Pakistan; asif.k.mian@gmail.com \\ ${ }^{5}$ Universiti Teknologi PETRONAS, Malaysia; manzoor.hashmani@utp.edu.my \\ * Correspondence: mobashar@utar.edu.my
}

\begin{abstract}
Aim of this study is to gather information regarding the sustainability development goals from the public as well as the organizations of Pakistan. A sample of 500 respondents each from five main cities including employs and general public is selected for their opinion regarding sustainability development goal. The level of awareness as well as level of commitment towards the fulfilment of Sustainable Development Goals varies across the cities of Pakistan due to difference in literacy level. The commitment to achieve Sustainable Development Goals of the organizations across the selected cities varies according to the nature of the business, volume and the membership with the United Nations. This study provides the policy makers with the ground level data regarding the awareness and commitment of Pakistan based organizations and public towards SDGs fulfilment. A glance towards the attitudes of the people towards the subject matter could also be seen through this study. This a comprehensive study conducted at federal and provincial level of Pakistan which has yielded ground realities towards the implementation of SDGs. The results could be used for policy making and planning at national level and also serve as bench mark for other countries.
\end{abstract}

Keywords: Developing country; Awareness towards SDGs; Literacy Rate

\section{Introduction}

According to the delineation approved by United Nations in their general assembly 1987, the concept of sustainability states that "development in every aspect that can encounter today's needs without compromising the ability of future generations to meets their own needs" [1]. Following the concept of sustainability approved by United Nations, the Sustainability Development Goals (SDGs) have been devised. All the countries which are a member of United Nations adopted these goals as their main motive to end the world's poverty, protect the atmosphere and make sure that all people get harmony and well-being [2]. The nations are targeting the achievement of SDGs by the end of 2030. 
Table 1: SDG Description

\begin{tabular}{|c|c|c|}
\hline Number & Goal & Description \\
\hline Goal 1 & No Poverty & $\begin{array}{l}\text { Eliminate the extreme poverty levels prevailing among the } \\
\text { people around the globe by } 2030 \text {. The poor people are measured } \\
\text { as the one's which live below the income level of } 1.25 \text { dollar per } \\
\text { day. }\end{array}$ \\
\hline Goal 2 & Zero Hunger & $\begin{array}{l}\text { To end the hunger and make sure that food is accessible to all } \\
\text { people by } 2030 \text {. Particularly the people specifically infants } \\
\text { residing in unsafe conditions should have a sufficient supply of } \\
\text { nutritious food throughout the year. }\end{array}$ \\
\hline Goal 3 & $\begin{array}{l}\text { Good Health and } \\
\text { Well-being }\end{array}$ & $\begin{array}{l}\text { Minimize the maternal death rate to as low as } 70 \text { per } 100,000 \\
\text { live births around the world. }\end{array}$ \\
\hline Goal 4 & Quality Education & $\begin{array}{l}\text { All the children (boys and girls) should have provision to quality } \\
\text { childhood developmental opportunities. }\end{array}$ \\
\hline Goal 5 & Gender Equality & $\begin{array}{l}\text { Elimination ferocity against women and girls publically and } \\
\text { privately including trafficking and all other forms of sexual } \\
\text { exploitation. }\end{array}$ \\
\hline Goal 6 & $\begin{array}{l}\text { Clean Water and } \\
\text { Sanitation }\end{array}$ & $\begin{array}{l}\text { Providing access to clean drinking water to all people of world } \\
\text { as well as provision of adequate sanitation and cleanliness. End } \\
\text { the open defecation with special focus towards females. }\end{array}$ \\
\hline Goal 7 & $\begin{array}{l}\text { Affordable and } \\
\text { Clean Energy }\end{array}$ & $\begin{array}{l}\text { Gradual and substantial increase in the share of renewable } \\
\text { energy resources. }\end{array}$ \\
\hline Goal 8 & $\begin{array}{l}\text { Decent Work and } \\
\text { Economic Growth }\end{array}$ & $\begin{array}{l}\text { Acquiring greater level of economic efficiency via } \\
\text { diversification, technology up gradation with inclusion of value } \\
\text { added and labour intensive sectors. }\end{array}$ \\
\hline Goal 9 & $\begin{array}{l}\text { Industry, } \\
\text { Innovation and } \\
\text { Infrastructure }\end{array}$ & $\begin{array}{l}\text { Development of sustainable and robust infrastructure. Regional } \\
\text { and cross border infrastructure should be developed in order to } \\
\text { support the economic growth. }\end{array}$ \\
\hline Goal 10 & Reduced Inequality & $\begin{array}{l}\text { The income growth of below } 40 \text { per cent of the population } \\
\text { should be achieved at a rate which is higher than national } \\
\text { average. }\end{array}$ \\
\hline Goal 11 & $\begin{array}{l}\text { Sustainable Cities } \\
\text { and Communities }\end{array}$ & $\begin{array}{l}\text { Guarantee the provision of standard, safe and reasonable } \\
\text { housing services to people. }\end{array}$ \\
\hline
\end{tabular}




\begin{tabular}{|c|c|c|}
\hline Goal 12 & $\begin{array}{l}\text { Responsible } \\
\text { consumption and } \\
\text { production }\end{array}$ & $\begin{array}{l}\text { Implementation of } 10 \text { year agenda including programs on } \\
\text { sustainable development and consumption. The developed } \\
\text { countries should take lead in implementing the agenda } \\
\text { considering the developing countries. }\end{array}$ \\
\hline Goal 13 & Climate Action & $\begin{array}{l}\text { Strengthen resilience and adaptive capacity to climate-related } \\
\text { hazards and natural disasters in all countries. }\end{array}$ \\
\hline Goal 14 & Life Below Water & $\begin{array}{l}\text { Prevention and reduction of marine pollution of various kinds. } \\
\text { Particularly land based form including debris and nutrient } \\
\text { pollution. }\end{array}$ \\
\hline Goal 15 & Life on Land & $\begin{array}{l}\text { Making sure those terrestrial and inland fresh water ecosystems } \\
\text { and their services. Particularly forests, wetlands as well as } \\
\text { mountains and dry lands. }\end{array}$ \\
\hline Goal 16 & $\begin{array}{l}\text { Peace and Justice } \\
\text { Strong Institutions }\end{array}$ & $\begin{array}{l}\text { Significant reduction of violence and every form and death } \\
\text { ratios. }\end{array}$ \\
\hline Goal 17 & $\begin{array}{c}\text { Partnerships to } \\
\text { achieve the Goal }\end{array}$ & $\begin{array}{l}\text { Strengthening of domestic resources which include supporting } \\
\text { of international resources of developing countries. }\end{array}$ \\
\hline
\end{tabular}

Source: United Nations Website

All the seventeen sustainability developmental goals tend to take action in one particular area possibly impact the outcomes in other aspects like social, economic and environmental sustainability [3]. In order to achieve the milestones mentioned in the sustainability development goals the nations are on their way. Some of the countries are quick in achieving these goals and others are slow. Sustainability development goals aim at 'zero' in major issues such as hunger, contagious diseases, and discriminatory behaviour towards women [4]. The accomplishment of these goals requires input in the form of finance, technology and knowledge from all the nations. The world considers the accomplishment of SDG's by 2030 as the biggest policy experiment of the human society of current time [5].

The sustainability goals can only be achieved by involving the society and public [6]. The specific agenda states that no one nation should be left behind ensuring the participation from every country. Though sustainable development goals vary a bit differently from one country to other, the implementation challenges also vary [7]. In order to enable the public involvement in the implementation of SDGs, it is deemed necessary that public opinion should be studied. To fill this gap, this study would gather the opinions from major cities of Pakistan.

According to the survey conducted by Myworld from about 10 million citizens, it was observed that sustainability development goals 3, 4 and 5 which are related to quality education, healthcare and employment opportunities were ranked highest in terms of significance [8]. The public surveys regarding the awareness of SDGs have been quite effective as they provided various information about the public opinion however two problems prevail [9]. First problem is that public surveys have generally been conducted among OECD countries however non-OECD countries have been targeted at a very small scale. Secondly the focus of the survey reports has barely been laid upon factors which influence the public support regarding the SDG implementation. This particular study would mainly be focused on Pakistan which is a perfect example of a developing country where the authorities need to work on real times to obtain the goals of sustainability. Pakistan is a nation that has set its priorities regarding SDGs which will enable it to join the league of upper middle class income countries by 
2030. Pakistan is among one of those countries who unanimously passed the SDG agenda in the Parliament. Pakistan realizes that the agenda of 2030 is all about taking actions regarding people, planet and prosperity.

\section{Literature Review}

The support provided by the individuals on certain cause depends on the attitudes of individuals towards that cause. The attitude of a person is defined as "a settled way of thinking or feeling about something" [9]. The personal evaluation of the person towards a subject and the tendency of in individual to predict form the building blocks of attitude.

These building blocks in a combined manner can predict the tendency of an individual to predict an entity [10]. By taking into consideration, the public attitude can be defined as "the assessments and judgments of the individuals that are related to the public matters"[10]. The focus of this study is primarily on the public awareness and support by the public of Pakistan. The proposed model of this study tends to explain about the process that how people collect and process the convincing information. The model can be processed either heuristically or systematically. Heuristic processing involves the usage of simplified decision rules namely heuristics for abrupt decision making. The systematic processing involves detailed and factual processing of information. The model actually guides in a manner that the individuals heavily rely on their heuristics hence minimizing the reliance on cognitive resources. The heuristic model assumes that cognitive or heuristic processing depends on degree to which the person is influenced [11].

\subsection{Public Opinion towards Sustainable Development}

With the advent of sustainable development goals novel research questions have started to arise [12]. The studies on the sustainability developmental goals and there awareness can be grouped into science and policy literature [13]. The studies which are science based mainly focus on the inter link of science with the sustainability development goals. There are other studies which argue that the sustainability development goals possess a linkage with collaborations and the efforts which are required for it. Furthermore, the studies which are focused on the policy tend to be deliberated on the governance mechanisms [14]. The governance mechanism involves efforts and arrangements made by the institutions to meet the sustainability development goals [15]. The studies which are focused on science perspective as well as policy perspective are crucial for the understanding of SDGs.

Participation at every level is important for the accomplishment for SDGs. Since the impact of sustainability could be seen on every level so the promotion of awareness among the public is crucial [16]. The studies which are based on the public awareness and opinions regarding the SDGs are scarce. In order to mobilize the individuals regarding the completion of sustainability development goals, it is necessary to increase the level of awareness among the citizens. Studies regarding awareness surveys mainly come from the high income countries as compared to the low income nations [14]. Therefore, a detailed and exhaustive analysis is required about the public attitudes. In order to gain a deeper comprehension about the SDGs, the related literature of public opinions has been reviewed in this study.

The goals of sustainability development encircle the economic, social and environmental perspectives. As per the findings of previous attitudinal surveys Sonetti, Brown [17]; Guan, Meng [18], the discrepancy between the attitude and action exist. Difference between the thinking and action prevails both at individual and national level. For instance, if an individual supports the idea of renewable energy it does not necessarily translates into his willingness to pay for it. On state level, the positive attitude of the individuals towards the SDGs does not lead to governmental action [19]. 
The gap between the public knowledge and attitude also prevails. For instance, the individuals who is knowledgeable does not necessarily hold a positive attitude towards solving global problems [19]. This current study would also aim to resolve the existent theoretical and empirical gap.

\subsection{Sustainability Reporting}

The reporting of sustainability goals is described as public disclamation of the sustainability goals on the economic, social and environmental perspectives. The SDGs have become the part of organizational goals and obligation is there about the disclosure of information that how the SDGs are met by the organizations [20]. The negative feedback from rest of community regarding the fulfilment of SDGs could be one of the major concerns of the organizations [21]. However on the other end, the disclosure of SDG accomplishment is counted as one of the major move towards the orientation of sustainability [22]. The reporting of sustainability can serve as a motivating factor for the enterprises as it can increase the goodwill of the companies by communicating their efforts and commitment towards the developmental goals. UNO has taken a United Nations Global Compact which is an initiative taken to motivate the organizations for committing to the sustainability goals. As per the findings of [23], currently the SDG disclosure is done on limited scale by the organizations. In another study carried out by [24], only $16 \%$ of the annual reports disclosed about their commitment towards sustainability development goals. It has been found that commitment of organizations with SDGs largely depends on the size of organization and their magnitude of intangible assets [16].

\subsection{Theoretical Framework}

The review of literature has majorly been conducted by keeping in view the economic, environmental and social perspectives in mind. The sustainability of the corporation has taken the form of a vital concept in the modern days [25]. The concept of corporate sustainability is to be modelled on the basis of the economic, social and environmental scope. The major focus of the concept lies on the fact that the current needs and wants of the firm and individuals should be met without compromising on the future of stakeholders [26].

The goals of sustainable development clearly signify the needs and wants of the stakeholder. The blending of the sustainability development goals within the core of businesses is an important topic of discussion in the sustainability literature [27]. The reporting of the compliance with SDGs in the annual reports is now a days recognized as an essential indicator of sustainability commitment of the companies [28]. The practical reality shows that small number of organizations currently declares their commitment to SDGs. The big organizations which are highly committed towards the dimensions of sustainability make sure about the disclosure of SDGs in their public reports. The commitment of the organizations towards the SDGs is higher by enterprises which are a member of United Nations network as compared to those companies which are not. 


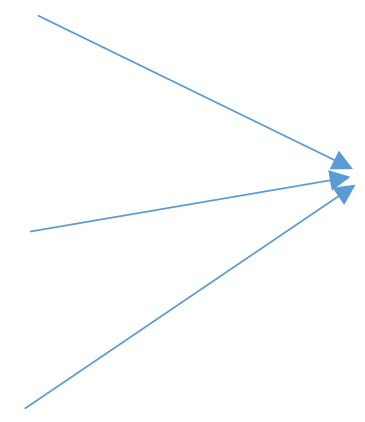

Figure 1: Theoretical Framework

The sustainability on corporate level is one of the vital issues for the long run success of the company. The sustainability development goals are framed with keeping the economic, societal and environmental aspects in mind. Sustainability development goals and common objectives of the nations around the globe are shared among them. The awareness of the public concerning the sustainability development goals could lead to a sense of fulfilment [29]. The commitment level of organizations could vary according to the business volume. Large organizations are more inclined towards the fulfilment of sustainability development because of their goodwill [30]. However, studies revealed that large companies show less commitment towards SDG fulfilment [16]. The medium sized corporations show an assurance towards the fulfilment of sustainability development goals [30]. Furthermore the corporations who are working over the sustainability activities tend to disclose these in their annual progress reports. However the drive of disclosure varies from company to company and region to region. The reporting of the sustainability development goals are more intense in the corporation which are a member of United Nations [6].

$\mathrm{H}_{1}$ : The organizations with higher business volume show more commitment towards the sustainability development goals fulfilment.

$\mathrm{H}_{2}$ : The organizations operating with medium business volume show more commitment towards the sustainability development goals fulfilment.

$\mathrm{H}_{3}$ : The organizations who are a member of United Nations Global Network show more commitment towards the sustainability development goals fulfilment.

$\mathrm{H}_{4}$ : The organizations that disclose their sustainability reports show more commitment towards the sustainability development goals fulfilment.

H5: People of Pakistan are aware about the SDG's fulfilment.

H6: People of Pakistan show commitment towards the attainment of SDG's fulfilment

\section{Research Methodology}

This particular study is based on quantitative methodology. The questionnaire was distributed both manually and online. The questionnaire consisted of the items regarding the awareness and fulfilment of the sustainability development goals. The questionnaire has also been distributed among the selected organizations via internet. The items of the questionnaire has been adopted from the studies of $[18,31]$. 


\subsection{Sampling and Data Collection}

Pakistan is regarded as one of the developing nations. Even then few organizations and people are showing their concerns for the environmental sustainability on the public forums [32]. In order to probe into the level of awareness and aware the public at the same, this study was carried out. A sample of 500 respondents each from five major cities of Pakistan including employs and general public was selected for their opinion regarding sustainability development goals. The respondents not only included the general public but also respondents from the organizations. The data was collected by personal administration of questionnaires from organizations and general public. The data was collected from federal and provincial capitals of Pakistan (Islamabad, Karachi, Quetta, Peshawar and Lahore). The information regarding the commitment of organizations with the SDGs was also collected by taking a look into the annual reports. Table 2 below shows the basic information regarding respondents and their cities.

\begin{tabular}{cccc}
\hline \multicolumn{4}{c}{ Table 2: Basic information of selected cities } \\
\hline City & Level & Population & Number of respondents \\
\hline Islamabad & Federal Territory & 1.015 million & 500 \\
\hline Lahore & $\begin{array}{c}\text { Provincial Capital of } \\
\text { Punjab }\end{array}$ & 11.13 million & 500 \\
\hline Quetta & $\begin{array}{c}\text { Provincial capital of } \\
\text { Balochistan }\end{array}$ & 1.001 million & 500 \\
\hline Peshawar & $\begin{array}{c}\text { Provincial capital of } \\
\text { KPK }\end{array}$ & 1.970 million & 500 \\
\hline Karachi & Provincial capital of & 14.91 million & 500 \\
& Sindh & & \\
\hline
\end{tabular}

Table 3 provides the information regarding the selected organizations and universities from all over the countries.

Table 3: Basic information regarding selected organizations

\begin{tabular}{|c|c|c|c|c|}
\hline Cities & Big companies & $\begin{array}{l}\text { Medium } \\
\text { companies }\end{array}$ & $\begin{array}{l}\text { United Nation's } \\
\text { member company }\end{array}$ & Universities \\
\hline Islamabad & $\begin{array}{l}\text { - Alcatel-Lucent } \\
\text { Pakistan Ltd } \\
\text { - Chevron Pakistan } \\
\text { Ltd }\end{array}$ & $\begin{array}{ll}\text { - } & \text { LearnoBots } \\
& \text { Pvt ltd } \\
\text { - } & \text { East west } \\
& \text { infinti }\end{array}$ & $\begin{array}{c}\text { - International } \\
\text { Labour } \\
\text { Organization }\end{array}$ & $\begin{array}{ll}\text { - } & \text { COMSATS } \\
\text { University } \\
\text { Islamabad } \\
\text { - } & \text { International } \\
\text { Islamic } \\
\text { University } \\
\text { Islamabad }\end{array}$ \\
\hline Lahore & $\begin{array}{l}\text { - Ashraf Group Of } \\
\text { Industries }\end{array}$ & $\begin{array}{c}\text { - } \\
\text { - } \\
\begin{array}{c}\text { Unique water } \\
\text { and }\end{array}\end{array}$ & $\begin{array}{l}\text { - World Food } \\
\text { Programme }\end{array}$ & $\begin{array}{l}\text { - The university of } \\
\text { Lahore } \\
\text { - } \quad \text { University of } \\
\quad \text { Central Punjab }\end{array}$ \\
\hline
\end{tabular}




\begin{tabular}{|c|c|c|c|c|}
\hline & $\begin{array}{ll}\text { - } & \text { Abacus } \\
\text { International HSE } \\
\text { Services (Pvt) Ltd }\end{array}$ & $\begin{array}{c}\text { engineering } \\
\text { limited }\end{array}$ & & \\
\hline Karachi & $\begin{array}{ll}\text { - } & \text { General tyres } \\
\text { - } & \text { Abbot } \\
& \text { Laboratories }\end{array}$ & $\begin{array}{ll}\text { - } & \text { Cool } \\
\text { equipment } \\
\text { engineering } \\
\text { - } & \text { AS industry } \\
\text { automation }\end{array}$ & $\begin{array}{c}\text { - United Nations } \\
\text { Children's } \\
\text { Fund, } \\
\text { Sind } \\
\text { Provincial } \\
\text { Programme } \\
\text { Office }\end{array}$ & $\begin{array}{ll}\text { - } & \text { Federal Urdu } \\
\text { University } \\
\text { Karachi } \\
\text { - } \\
\text { SZABIST } \\
\text { Karachi }\end{array}$ \\
\hline Quetta & $\begin{array}{ll}\text { - } & \text { Merck (Private) } \\
\text { Limited } \\
\text { - } \quad \text { KSB Pumps } \\
\text { Company Limited }\end{array}$ & $\begin{array}{ll}- & \text { BNZ } \\
& \text { enterprises } \\
\text { - } & \text { COBIA } \\
& \text { International }\end{array}$ & $\begin{array}{l}\text { World Food } \\
\text { Programme }\end{array}$ & $\begin{array}{l}\text { - University of } \\
\text { Baluchistan } \\
\text { Baluchistan } \\
\text { University of } \\
\text { Information } \\
\text { Technology, } \\
\text { Engineering and } \\
\text { Management } \\
\text { Sciences }\end{array}$ \\
\hline Peshawar & $\begin{array}{ll}\text { - } & \text { Pakcom limited } \\
\text { - } & \text { Pakistan express } \\
& \text { limited }\end{array}$ & $\begin{array}{l}\text { - } \mathrm{Haq} \\
\text { chemicals } \\
\text { - } \quad \text { KB strengths }\end{array}$ & $\begin{array}{l}\text { - World Food } \\
\text { Programme }\end{array}$ & $\begin{array}{ll}\text { - } & \text { Abasyn } \\
& \text { University } \\
\text { - } & \text { Islamia College } \\
& \text { University }\end{array}$ \\
\hline
\end{tabular}

\section{Findings}

This section may be divided by subheadings. It should provide a concise and precise description of the experimental results, their interpretation as well as the experimental conclusions that can be drawn.

\subsection{Islamabad}

Islamabad is the federal capital of Pakistan where representation from all over the country is present. The results after analysis show that respondents from Islamabad are aware of the sustainability development goals. The awareness is prevalent not only among the people but also among the firms. The large firms did not show high level of commitment towards the fulfilment of sustainability development goals ( $\mathrm{t} 2.42 ; \mathrm{p}$ 0.016). The results confirm that medium sized firms operating in capital city of Pakistan are striving for the accomplishment of sustainability development goals ( $t$ 3.679; $p$ 0.002). Furthermore, it is evident from the results shown that people living in Islamabad are educated and have awareness towards sustainability development goals ( $t 3.668 p 0.0020)$. The companies have introduced a new practice of disclosing their sustainability information in their company reports. The companies which disclose their sustainability information seem to be more committed towards the fulfilment of the goals ( $1.660 \mathrm{p}$ 0.097). Various firms' usually non-profitable firms which are linked with the United Nations show more commitment towards the agenda of the SDG ( $t 4.081 \mathrm{p} \mathrm{0.000).}$ The people who are mindful of the importance of sustainable practices in the country show a commitment and motivation towards the accomplishment of the goals ( $\mathrm{t} 6.725 \mathrm{p} 0.000)$.

Table 4: Results of Islamabad 


\begin{tabular}{lcc}
\hline Relationship & T Statistics & P Values \\
\hline AW -> SDGF & 3.668 & 0.002 \\
\hline BV -> SDGF & 2.424 & 0.016 \\
\hline COM -> SDGF & 6.725 & 0.000 \\
\hline MBV -> SDGF & 3.679 & 0.002 \\
\hline SD -> SDGF & 1.660 & 0.097 \\
\hline UNM -> SDGF & 4.081 & 0.000
\end{tabular}

(AW awareness; BV big volume companies; COM commitment; MBV medium business volume, SD sustainability disclosure, UNM

Unite Nation Member)

\subsection{Karachi}

Karachi is the biggest and most populous city of Pakistan. For the implementation and tracking of sustainability development goals, SDG units have been developed. Karachi is a city where various people with comparatively higher educational level exist because of the presence of large number of universities and educational institutes. Being a big city in Sindh rapid urbanization is also taking place. The data has been collected from universities, companies and public residing in the city.

Table 5: Results of Karachi

\begin{tabular}{lcc}
\hline & T Statistics & P Values \\
\hline AW -> SDGF & 3.446 & 0.006 \\
\hline BV -> SDGF & 2.743 & 0.015 \\
\hline COM -> SDGF & 5.655 & 0.000 \\
\hline MBV -> SDGF & 1.782 & 0.082 \\
\hline SD -> SDGF & 1.865 & 0.080 \\
\hline UNM -> SDGF & 4.075 & 0.000
\end{tabular}

(AW awareness; BV big volume companies; COM commitment; MBV medium business volume, SD sustainability disclosure, UNM

United Nation Member)

The results after analysis show that awareness exists amongst the public of Karachi. The statistics reveal that general public is quite aware of the sustainability development goals designed by United Nations (t 3.446; $\mathrm{p}$ 0.006). Similarly, commitment towards the fulfilment of SDGs has also been checked in relationship with the business volume. The organizations with big business volume show less commitment towards the accomplishment of the goals ( $\mathrm{t} 2.743 ; \mathrm{p}$ 0.015). The companies with medium business volume have higher level of commitment towards fulfilment of sustainable development goals. The statistical values ( $t$ 1.782; $\mathrm{p}$ 0.082) confirm the commitment towards the fulfilment is quite truncated in the general public. Furthermore, the organizations which are the members of United Nations show a strong obligation towards the fulfilment ( $t$ 4.075; $p$ 0.000). In addition to the disclosure of other information by the companies in their annual reports, an emerging trend of disclosing the commitment towards sustainability is also taking place ( $\mathrm{t} 1.865 ; \mathrm{p} 0.080)$. Even though the people are aware regarding the importance of sustainability yet it is not an assurance that they might fell committed towards their fulfilment. However the results illustrate that the people are also committed and motivated towards the accomplishment of the goals for the betterment of the city and country.

\subsection{Lahore}


Lahore is the provincial capital of Punjab one of the biggest cities in Punjab as well as in the country. This historic city is seriously suffering from rapid urbanization and there exists a need of handling the resources in a sustainable and effective manner. The data has also been collected from Lahore alike previous cities.

\begin{tabular}{lcc}
\hline & Table 6: Results of Lahore & \\
\hline & T Statistics & P Values \\
\hline AW -> SDGF & 3.553 & 0.004 \\
\hline BV -> SDGF & 3.777 & 0.009 \\
\hline COM -> SDGF & 1.865 & 0.075 \\
\hline MBV -> SDGF & 1.782 & 0.082 \\
\hline SD -> SDGF & 1.885 & 0.084 \\
\hline UNM -> SDGF & 4.334 & 0.001 \\
\hline
\end{tabular}

(AW awareness; BV big volume companies; COM commitment; MBV medium business volume, SD sustainability disclosure, UNM

Unite Nation Member)

The results show a different outcome in the case of Lahore as compared to other cities. The general public of the provincial capital of Punjab is aware of the importance of sustainability and the need of the hour to comply with the sustainability development goals ( $\mathrm{t} 3.553 ; \mathrm{p} 0.004)$. The statistical analysis shows that the big companies in Lahore are committed towards the fulfilment of SDGs ( $t$ 3.777; $p$ 0.009). The citizens of Lahore are although aware of the importance of SDGs fulfilment but yet they do not show the commitment towards the fulfilment of these goals for their betterment $(\mathrm{t}$ 1.865; $\mathrm{p}$ 0.075). In contrast to the big volume companies, the medium sized organizations do not show high level of obligation towards the fulfilment of SDGs ( $t$ 1.782; $p$ 0.0082). The companies based in Lahore region do not show a high degree of commitment towards the disclosure of sustainability information ( $p 1.885 ; \mathrm{t} 0.084$ ). Furthermore the companies which are member of United Nations alike other cities show high level of commitment towards fulfilment of sustainable development goals ( $\mathrm{p}$ 4.334; $\mathrm{t}$ 0.001).

\subsection{Quetta}

Quetta is the provincial capital and the largest city of Baluchistan. The number of companies working in Quetta is quite few. The education level of the citizens is also not as high as other big cities for instance Lahore and Karachi. The data was also collected from Quetta and the results have depicted quite contrasting outcomes as compared to other cities. The awareness of the public of Quetta regarding sustainability and the goals is quite low as compared to other cities as evidently seen through the result. On similar lines, the organizations of both large and medium sized enterprises have a less inclination towards the SDG fulfilment. Since there is a lack of awareness in the public so the lack of commitment towards fulfilment also prevails. The organizations which are working under the membership of United Nations for instance NGOs however show a proclivity towards the sustainability goal fulfilment ( $\mathrm{t}$ 4.004; $\mathrm{p} 0.009$ ).

Table 7: Results of Quetta

\begin{tabular}{lcc}
\hline & T Statistics & P Values \\
\hline AW -> SDGF & 1.753 & 0.074 \\
\hline BV -> SDGF & 1.777 & 0.079 \\
\hline COM -> SDGF & 1.865 & 0.075 \\
\hline MBV -> SDGF & 1.782 & 0.082 \\
\hline SD -> SDGF & 1.885 & 0.084 \\
\hline UNM -> SDGF & 4.004 & 0.009 \\
\hline
\end{tabular}


(AW awareness; BV big volume companies; COM commitment; MBV medium business volume, SD sustainability disclosure, UNM Unite Nation Member)

\subsection{Peshawar}

Peshawar is the provincial capital of Khyber Pakhtunkhwa as well as a historical city of Pakistan. It is one of the cities which have a rich culture and history. There are a number of educational institutes in the city with many organizations (public and private) operating in the city. The results of the data analysis show that the public awareness regarding the sustainability development goals and their fulfilment is high ( $\mathrm{t} 3.540 ; \mathrm{p}$ 0.005). Furthermore, the big business volume companies show higher commitment towards fulfilment of SDGs ( $t 3.424 ; p 0.006$ ) as compared to the medium sized business volume companies ( $\mathrm{t} 2.340 ; \mathrm{p}$ 0.020). The commitment of the people as well of companies of Peshawar shows a commitment towards the attainment of sustainability development goals (t 5.704; p 0.000). The trend towards the disclosure of information regarding sustainability practices is limited in companies as shown by the results ( $\mathrm{t} 1.442 ; \mathrm{p} 0.074)$. The companies which are a member of United Nations show a commitment towards disclosure and fulfilment of the sustainability goals ( $\mathrm{t} 3.079 ; \mathrm{p}$ $0.008)$.

\begin{tabular}{ccc}
\hline & Table 8: Results of Peshawar & \\
\hline & T Statistics & P Values \\
\hline AW -> SDGF & 3.101 & 0.009 \\
\hline BV -> SDGF & 3.424 & 0.006 \\
\hline COM -> SDGF & 5.704 & 0.000 \\
\hline MBV -> SDGF & 2.340 & 0.020 \\
\hline SD -> SDGF & 1.442 & 0.074 \\
\hline UNM -> SDGF & 3.079 & 0.008
\end{tabular}

(AW awareness; BV big volume companies; COM commitment; MBV medium business volume, SD sustainability disclosure, UNM

Unite Nation Member)

\section{Findings}

Constant efforts for improving the environmental status and better life are referred as sustainability. This phrase of sustainable development has been part of many debates around the world with an underlined idea of vision and future [33]. The sustainable development goals have been tailored in order to minimize the problems which are occurring around the globe. Although it is difficult to address all the SDGs simultaneously at a single point of time but a deep understanding about the cause and the challenges associated with it can help in the development of better humane life for people around the globe [34]. The study regarding sustainable development goals has been conducted in Pakistan which provides interesting insights [35]. The table below (Table 9) provides the comparative analysis among the cities of Pakistan. The data regarding the awareness has been gathered at a big scale and the awareness levels shown by the data indicate the special meanings. Islamabad is the federal capital of Pakistan with many universities in it and various companies have opened their head offices in the capital city [36]. The representation of people from all over Pakistan is present in the city. The people residing in Islamabad are aware about the sustainability development goals. With world class amenities, constant supply of internet and $87 \%$ literacy rate, 
Islamabad is quite aware of the concept of sustainability and the goals devised by United Nations about the sustainability [37].

Moving on to the Lahore, it is the provincial capital of the province of Punjab. The city of Lahore also has numerous universities in the city and a literacy rate of $65 \%$ with a big number of companies working there [38]. The population of Lahore is also increasing at a fast pace hence there is an immediate need of sustainability. The results indicate that the awareness regarding the concept of sustainable development goals prevails in the public of the city. A possible explanation of such result could be due to literacy rate with better supply of resources as compared to other cities of Punjab. The city is also populous which is urbanizing at a very fast pace so the fulfilment of sustainable development goals and awareness quite relevant to the city [39].

Quetta is the provincial capital of Baluchistan. As compared to other provinces and big cities of Pakistan, there are limited number of educational institutes in the city and the resources are less [미]. The literacy rate of Quetta is $40 \%$, hence justifying the results that awareness level about the SDGs among the people is quite low. Although there are number of organizations which are working in Quetta and other areas of Baluchistan for sustainability and other SDGs like poverty elevation, yet the low education level might be responsible for the non-awareness regarding the concept [1] .

Moving on further, Peshawar is the provincial capital of Khyber Pakhtunkhwa. Unlike, Islamabad, Lahore and Karachi where the awareness about the sustainable development goals exist at quite high level, Peshawar is less aware about the idea and the cause [르. The literacy rate in Peshawar is 56\% which is low as compared to other cities but highest in KPK [ $\underline{43}]$. The existence of people from across country is also limited in Quetta as well Peshawar hence the exchange of knowledge also does not take place at a wider level.

The last city which was selected for the data collection is Karachi which is the capital as well as largest city of Sindh. This city being over crowded with people has major concerns for the sustainability and the related goals. The literacy rate of Karachi is $65.26 \%$ which is highest in Sindh and at fourth number after Islamabad, Lahore and Rawalpindi. Population of Karachi consist of people from across Pakistan and foreigners as well thus making its culture diverse. [44]]. The existence of folks from all walks of life also makes the transfer of knowledge much easy. The possible reason behind the positive result of awareness could be the high literacy rate as well as the optimum knowledge transfer.

The companies from all the selected cities were considered in order to check for their engagement towards the SDG fulfilment. The organizations were selected according to the business volume as well as their attachment with United Nations. The organizations with bigger business volumes generally seem to be less committed towards the fulfilment of sustainable development goals [ㄴ5]. The selected organizations from Islamabad show a very minimal concern regarding the fulfilment of sustainable development goals. Less commitment towards the cause has also been shown by the companies from Quetta and Karachi. The big organizations working in those cities are aware of the importance of sustainability in the environment but due to their big volume they seem less interested in complying with the efforts of attaining the developmental goals [느] .

The medium sized enterprises were also selected across the country for analysis of their activities towards the fulfilment of sustainable development goals. The medium sized enterprises show pledge towards the fulfilment of SDGs however the organizations in other cities with medium volume are not much committed towards such activities. Furthermore, an intention towards the commitment of sustainability development goals is largely shown by public and companies of Islamabad, Peshawar and Karachi [47]. On the other hand, Lahore and Quetta has less commitment towards the matter. 
The less literacy rate in Quetta and lack of attention by the Federal government and media might be the reason towards the reluctant attitude. Lahore is the city which is growing rapidly and urbanizing with every single day yet the public and the business organizations apparently do not seem committed towards the fulfilment of the SDGs [표].

The disclosure of the information in the annual reports of the companies concerning the sustainability activities builds up the goodwill of the company. However, contrary to the observed patterns around the world, the Pakistan based firms across the country show less commitment towards the disclosure of SDGs fulfilment activities. Although Pakistan became the signatory of the sustainability development goals very fast yet they are quite far behind from fulfilment SDGs.

Table 9: Comparative Analysis of the cities

\begin{tabular}{ccccccccccc}
\hline & \multicolumn{2}{c}{ Islamabad } & \multicolumn{2}{c}{ Lahore } & \multicolumn{2}{c}{ Quetta } & \multicolumn{2}{c}{ Peshawar } & \multicolumn{2}{c}{ Karachi } \\
\hline & $\mathbf{T}$ & $\mathbf{P}$ & $\mathbf{T}$ & $\mathbf{P}$ & $\mathbf{T}$ & $\mathbf{P}$ & $\mathbf{T}$ & $\mathbf{P}$ & $\mathbf{T}$ & $\mathbf{P}$ \\
& Value & Value & Value & Value & Value & Value & Value & Value & Value & Value \\
\hline AW -> SDGF & 3.668 & 0.002 & 3.553 & 0.004 & 1.753 & 0.074 & 3.101 & 0.009 & 3.446 & 0.006 \\
\hline BV -> SDGF & 2.424 & 0.016 & 3.777 & 0.009 & 1.777 & 0.079 & 3.424 & 0.006 & 2.743 & 0.015 \\
\hline COM -> SDGF & 6.725 & 0.000 & 1.865 & 0.075 & 1.865 & 0.075 & 5.704 & 0.000 & 5.655 & 0.000 \\
\hline MBV -> SDGF & 3.679 & 0.002 & 1.782 & 0.082 & 1.782 & 0.082 & 2.340 & 0.020 & 1.782 & 0.082 \\
\hline SD -> SDGF & 1.660 & 0.097 & 1.885 & 0.084 & 1.885 & 0.084 & 1.442 & 0.074 & 1.865 & 0.080 \\
\hline UNM -> SDGF & 4.081 & 0.000 & 4.334 & 0.001 & 4.004 & 0.009 & 3.079 & 0.008 & 4.075 & 0.000 \\
\hline
\end{tabular}

\section{Conclusion}

The results of the study show that the policymakers, scholars and academicians should associate the level of education with public awareness and understanding regarding the sustainable development goals. This paper explored that the general public residing in the developing countries like Pakistan understands the importance of sustainable development goals yet they do not show much interest in the fulfilment of these goals, although the results vary based on the region. It has been concluded from the data that support level in public as well as organizations is mainly dependent over the knowledge about the sustainable development goals. The results imply that awareness campaigns for public and organizations regarding the sustainability development goals are necessary.

Practically the acceptance and support of the cause for the general public as well as organizations could be attained by enhancing the comprehension among the ecologists and environmentalist. Furthermore, the general opinion within the cities of Pakistan is that fulfilment and implementation of these goals is the domain of the government rather than the environment specialists as the government has the authority and resources to achieve SDGs.

\subsection{Theoretical Contribution}

This study makes a unique contribution towards reporting of SDGs fulfilment among public and organizations of Pakistan. The plotting related to the current level of engagement of the sustainable development goals developed by United Nations shows varied results regarding awareness, disclosure and commitment as per the nature of business of organizations. We can conclude that the awareness exists among the people and organizations of Pakistan but yet the practices of disclosure are limited. This study makes a novel contribution to the body of knowledge as it provides first-hand 
knowledge from the context of Pakistan. However as no research is free of limitations, such is the case with this study. The sample has been collected from five major cities of Pakistan only. The information regarding the SDGs in Pakistan based firms has been collected only from the reports which were available online. The framework of the study could be extended cross borders in order to maximize the generalizability of the results. The underlined statistical inferences and outcomes can serve as the foundations for the policy makers and the government officials to take a step forward towards the fulfilment of the United Nations goals. From the managerial aspect, this study highlights the companies that address the sustainability perspective in terms of economic, environmental and social dimensions in their business routines.

\subsection{Practical Contribution}

The implementation of sustainability development goals could lead to the economic, societal and environmental well-being of the society. The findings of the study have a utility for the policy makers, scholars and researchers for improved understanding regarding the general thinking and awareness level. The outcome could assist in development of authentic policies for the implementation of SDGs across the country.

Although there is a general consensus on the importance of fulfilment of sustainable development goals yet there are rare studies that have focused on the awareness of SDGs in Pakistan and level of commitment according to the nature of organization. This particular study has provided an in-depth empirical observations and analysis of the under lying hypotheses. This study also addresses the knowledge gap and makes a legitimate contribution towards the comprehension of attitude and perception of public and companies. Being a developing nations, the understanding of the SDGs could be the primary step towards the policy making. 


\section{References}

1. Schroeder, P., K. Anggraeni, and U. Weber, The relevance of circular economy practices to the sustainable development goals. Journal of Industrial Ecology, 2019. 23(1): p. 77-95.

2. Salvia, A.L., et al., Assessing research trends related to Sustainable Development Goals: Local and global issues. Journal of cleaner production, 2019. 208: p. 841-849.

3. Chams, N. and J. García-Blandón, On the importance of sustainable human resource management for the adoption of sustainable development goals. Resources, Conservation and Recycling, 2019. 141: p. 109-122.

4. Lu, Y., et al., Policy: five priorities for the UN sustainable development goals. Nature, 2015. 520(7548): p. 432-433.

5. Sarvajayakesavalu, S., Addressing challenges of developing countries in implementing five priorities for sustainable development goals. Ecosystem Health and Sustainability, 2015. 1(7): p. 1-4.

6. Griggs, D., et al., Policy: Sustainable development goals for people and planet. Nature, 2013. 495(7441): p. 305.

7. Tabrizian, S., Technological innovation to achieve sustainable development-Renewable energy technologies diffusion in developing countries. Sustainable Development, 2019. 27(3): p. 537-544.

8. Fayomi, O., et al., The challenge of Nigeria researcher in meeting up with sustainable development goal in 21st Century. Energy Procedia, 2019. 157: p. 393-404.

9. Leal Filho, W., et al., Sustainable Development Goals and sustainability teaching at universities: Falling behind or getting ahead of the pack? Journal of Cleaner Production, 2019. 232: p. 285-294.

10. Dalampira, E.S. and S.A. Nastis, Mapping sustainable development goals: A network analysis framework. Sustainable Development, 2019.

11. Andria, J., G. di Tollo, and R. Pesenti, A heuristic fuzzy algorithm for assessing and managing tourism sustainability. Soft Computing, 2019: p. 1-14.

12. Robert, K.W., T.M. Parris, and A.A. Leiserowitz, What is sustainable development? Goals, indicators, values, and practice. Environment: science and policy for sustainable development, 2005. 47(3): p. 8-21.

13. Nilsson, M., D. Griggs, and M. Visbeck, Policy: map the interactions between Sustainable Development Goals. Nature, 2016. 534(7607): p. 320-322.

14. Gupta, J. and C. Vegelin, Sustainable development goals and inclusive development. International environmental agreements: Politics, law and economics, 2016. 16(3): p. 433448.

15. Hák, T., S. Janoušková, and B. Moldan, Sustainable Development Goals: A need for relevant indicators. Ecological Indicators, 2016. 60: p. 565-573.

16. Stafford-Smith, M., et al., Integration: the key to implementing the Sustainable Development Goals. Sustainability Science, 2017. 12(6): p. 911-919.

17. Sonetti, G., M. Brown, and E. Naboni, About the triggering of UN sustainable development goals and regenerative sustainability in higher education. Sustainability, 2019. 11(1): p. 254. 
18. Guan, T., et al., Public Attitudes toward Sustainable Development Goals: Evidence from Five Chinese Cities. Sustainability, 2019. 11(20): p. 5793.

19. Halkos, G., S. Matsiori, and S. Dritsas, Stakeholder engagement for sustainable development and their suggestions for environmental policy: The case of Mediterranean monk seal. Sustainable Development, 2019. 27(3): p. 461-473.

20. Ioannou, I. and G. Serafeim, The consequences of mandatory corporate sustainability reporting. Harvard Business School research working paper, 2017(11-100).

21. Herremans, I.M., J.A. Nazari, and F. Mahmoudian, Stakeholder relationships, engagement, and sustainability reporting. Journal of Business Ethics, 2016. 138(3): p. 417-435.

22. Abid, M., et al. Sustainability reporting as a way to foster entrepreneurial universities. in EurOMA Conference, June 24-26 2018, Budapest, Hungary. 2018.

23. Schramade, W., Investing in the UN sustainable development goals: opportunities for companies and investors. Journal of Applied Corporate Finance, 2017. 29(2): p. 87-99.

24. Rosati, F. and L.G. Faria, Addressing the SDGs in sustainability reports: The relationship with institutional factors. Journal of cleaner production, 2019. 215: p. 1312-1326.

25. Dyllick, T. and K. Hockerts, Beyond the business case for corporate sustainability. Business strategy and the environment, 2002. 11(2): p. 130-141.

26. Van Marrewijk, M. and M. Werre, Multiple levels of corporate sustainability. Journal of Business ethics, 2003. 44(2-3): p. 107-119.

27. Baumgartner, R.J. and D. Ebner, Corporate sustainability strategies: sustainability profiles and maturity levels. Sustainable Development, 2010. 18(2): p. 76-89.

28. Montiel, I., Corporate social responsibility and corporate sustainability: Separate pasts, common futures. Organization \& Environment, 2008. 21(3): p. 245-269.

29. Omisore, A.G., et al., Awareness and knowledge of the sustainable development goals in a University Community in Southwestern Nigeria. Ethiopian journal of health sciences, 2017. 27(6): p. 669-676.

30. Jones, P., D. Hillier, and D. Comfort, The sustainable development goals and business. International Journal of Sales, Retailing and Marketing, 2016. 5(2): p. 38-48.

31. Fonseca, L. and F. Carvalho, The Reporting of SDGs by Quality, Environmental, and Occupational Health and Safety-Certified Organizations. Sustainability, 2019. 11(20): p. 5797.

32. Rehman, K., A.A. Shah, and K. Ahmed. E-Government Identification to Accomplish Sustainable Development Goals (UN 2030 Agenda) A Case Study of Pakistan. in 2018 IEEE Global Humanitarian Technology Conference (GHTC). 2018. IEEE.

33. Hald, M., Sustainable urban development and the Chinese eco-city: concepts, strategies, policies and assessments. 2009.

34. Carley, M. and H. Smith, Urban development and civil society: The role of communities in sustainable cities. 2013: Routledge.

35. Waldmüller, J.M., H. Jamali, and N. Nogales, Operationalizing sustainable development goals in vulnerable coastal areas of Ecuador and Pakistan: Marginalizing human development? Journal of Human Development and Capabilities, 2019. 20(4): p. 468-485.

36. Malik, M.N., et al., Investigating Students' Sustainability Awareness and the Curriculum of Technology Education in Pakistan. Sustainability, 2019. 11(9): p. 2651. 
37. Malik, M.I., et al., Contradictory results on environmental concern while re-visiting green purchase awareness and behavior. Asia Pacific Journal of Innovation and Entrepreneurship, 2019.

38. Naqvi, S.A., et al., Implementation of Sustainable Practices in Textile Processing Mills of Lahore, Pakistan. Polish Journal of Environmental Studies, 2020. 29(1).

39. Javaid, S., F. Aziz, and T. Arshad, A study to explore Post Graduate Student's Knowledge, Attitudes and Behaviors towards Sustainable Development in Lahore.

40. Ali, A., et al., Smart and Sustainable Urban Water Management in Quetta City, Pakistan.

41. Qutub, S.A., et al., Subsidy and sustainability in urban sanitation: the case of Quetta Katchi Abadis environment management programme. Waterlines, 2008: p. 205-223.

42. Omair, M., et al., Sustainable development tool for Khyber Pakhtunkhwa's dimension stone industry. Technol. J, 2015. 20: p. 160-165.

43. Kalsoom, Q., A. Khanam, and U. Quraishi, Sustainability consciousness of pre-service teachers in Pakistan. International Journal of Sustainability in Higher Education, 2017.

44. Awan, U. and A.S. Abbasi, Environmental sustainability through determinism the level of environmental awareness, knowledge and behavior among business graduates. Res. J. Environ. Earth Sci, 2013. 5(9): p. 505-515.

45. Razzaq, S., et al., Policy research institutions and the health SDGs: building momentum in South Asia-Pakistan country study. 2017.

46. Asghar, Z. and M. Umar, Expected Time to Achieve SDG 4.6: A Disaggregated Data Analysis for Pakistan. 2017.

47. Waheed, A. and R.B. Initiative, National Responsibility Framework for Sustainable Development: Responsible Business Framework integrating SDGs. 2019.

48. Asad, S., 6 SDGs in Pakistan. Social Development and the Sustainable Development Goals in South Asia, 2019. 